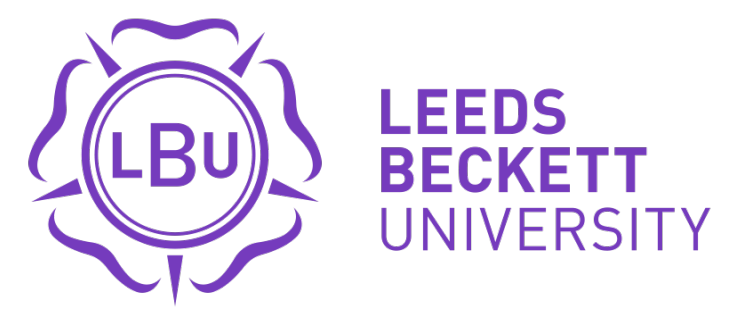

Citation:

Rich, R (2018) 'Life will pass quickly for me': Women, clocks and timekeeping in nineteenth-century France. Gender and History, 31 (1). pp. 41-59. ISSN 0953-5233 DOI: https://doi.org/10.1111/14680424.12374

Link to Leeds Beckett Repository record:

https://eprints.leedsbeckett.ac.uk/id/eprint/4430/

Document Version:

Article (Accepted Version)

This is the peer reviewed version of the following article: Rich, R. (2019), 'Life will pass quickly for me': Women, Clocks and Timekeeping in NineteenthCentury France. Gender \& History, 31: 41-59, which has been published in final form at https://doi.org/10.1111/1468-0424.12374. This article may be used for non-commercial purposes in accordance with Wiley Terms and Conditions for Use of Self-Archived Versions.

The aim of the Leeds Beckett Repository is to provide open access to our research, as required by funder policies and permitted by publishers and copyright law.

The Leeds Beckett repository holds a wide range of publications, each of which has been checked for copyright and the relevant embargo period has been applied by the Research Services team.

We operate on a standard take-down policy. If you are the author or publisher of an output and you would like it removed from the repository, please contact us and we will investigate on a case-by-case basis.

Each thesis in the repository has been cleared where necessary by the author for third party copyright. If you would like a thesis to be removed from the repository or believe there is an issue with copyright, please contact us on openaccess@leedsbeckett.ac.uk and we will investigate on a case-by-case basis. 


\section{'Life will pass quickly for me': Women, clocks and timekeeping in nineteenth-century France}

"I go with Annette and Francine to Versailles after lunch on the American railway, to see the park and the paintings.'1

'Edmond very busy with his inventory, leaves one hour earlier, dines at Gravalle restaurant, at his study until 8:00—and home at 9:30.'2

'I go to mass at noon, Edmond leaves as 11:00 with Henry Pucey to Versailles where they stroll and return home at 6:00'3

1870-71 were years of political upheaval and violence. But for the anonymous writer of the words above, life carried on with the usual round of visits, meals and letter writing. For the whole of this fraught period in France's history, the anonymous Bourgeois parisienne kept writing her diary, leaving a rare record of how a respectable, middle-class, married woman from the suburbs spent her time, what she considered noteworthy, and what time meant to her. ${ }^{4} \mathrm{Her}$ meticulous notes, about her own activities and the comings and goings of her husband and son, point to the way that bourgeois women's domestic responsibilities included accounting for the family's time..$^{5}$ The modern experience of timekeeping and temporality is only partially understood if historians continue to use separate spheres as a paradigm for understanding the lives of bourgeois women. Recent scholarship problematizing this approach highlights how bourgeois women interacted with each other, and with men and the public; this opens up new possibilities for considering timekeeping as gendered rather than as having distinctly masculine and feminine aspects. ${ }^{6}$ 
Historians who define the temporality of modernity as relentlessly regular and oppressively accurate do so by ignoring domestic lives, and the complex range of ways in which time could be measured in the nineteenth century. Jacques Le Goff's 'Temps de l'Église et temps de marchands,' and E. P. Thompson's 'Time, Work Discipline and Industrial Capitalism,' both published in the 1960s, were influential in setting the tone for the social history of time. ${ }^{7}$ Both scholars had in mind work patterns and economic relations, rather than the experience of time in everyday life. ${ }^{8}$ However by situating timekeeping outside of the home and its daily routines, Le Goff and Thompson excluded the experience of bourgeois women--'protected' as they were from the cash nexus--from our understanding of modernity's oppressive temporal regime. As Lisa Tiersten and others have noted, contemporaries saw women as more natural and less rational than men, a trope subsequently built on by historians who assume that women's lives lay outside of productive work and mechanical timekeeping. ${ }^{9}$ Recent women's histories of nineteenth-century France have suggested that-to a larger extent than previously acknowledged-women were operating in both the public and the private spheres, for example acting as go-betweens between men who could not easily communicate with one another across political lines. ${ }^{10}$ Historians following the Le Goff/Thompson model have failed to perceive the extent to which cyclical, repetitive time continued to be part of the modern experience, as exemplified in women's diaries charting their families' lives, and in domestic manuals showing great interest in the recurrent time of the seasons. ${ }^{11}$

Ever since Jacques Le Goff argued for a shift from ecclesiastic to economic timekeeping as a key moment in the emergence of modernity, the debate has 
been over when this change happened, rather than over whether the transition was ever complete. In particular, there has been too little research on the nineteenth century, as historians have assumed that by the end of the French Revolution mechanical timekeeping's dominance was complete. ${ }^{12}$ Much of this research, though, depends on measuring public time and work time, and thus excludes areas of experience outside of the formal economy. ${ }^{13}$ Among these omissions is the experience of bourgeois women, who as managers of the family timetable were central to the creation of the time-discipline for which the European middle classes came to be known. Central to a reconsideration of modern temporality is new research suggesting that we have misunderstood contemporary references to time; Corine Maitte and Didier Terrier argue that while we think of an hour as specifically 3,600 seconds, historically an hour was a notional unit of time into which specific tasks could be divided. When considering, for example, women's time in the kitchen, devoted to completing a series of familiar tasks, this way of refering to units of clock time to denote taskoriented time is indeed significant. ${ }^{14}$ Building on Paul Glennie and Nigel Thrift's concept of multiple, overlapping temporal networks, this paper seeks to rethink the way histories of modern time have viewed women's quotidian experience. 15 In arguing that women like the anonymous Parisian diarist were flexible timekeepers who managed their families' routines and moved seamlessly between public clock time, cyclical routines, and more personal timekeeping practices, this paper seeks to demonstrate that nineteenth-century time cannot be seen as entirely mechanical, but rather as fluid and malleable, something which a more gendered reading can bring into clear relief. 
When Joan Kelly asked ‘Did Women have a Renaissance?' in 1976, she woke scholars up to the ways in which time has been measured according to the great events of public life, but in which the continuities characteristic of domesticity and women's lives have been overlooked. ${ }^{16}$ In her work on the lives of bourgeois women in northern France, Bonnie Smith follows Julia Kristeva in arguing for a 'women's time' which prioritized women's cyclical reproductive rhythms to argue for a gendered experience of time. ${ }^{17}$ Smith argues women 'ignored modern notions of time' and had a 'traditional, rather than a modern, sense of history' which she sees as manifestations of their reproductive role and biological cycle. ${ }^{18}$ Sociologists like Rita Felski suggest that looking at specific tasks offers a better way to understand women's temporalities. ${ }^{19}$ The history of bourgeois women's clock ownership combined with their daily routines and domestic chores hints at a complex and layered sense of time. Women kept time for their families: got meals to the table, kept children organized, marked important events in their diaries. In cooking, they may have watched the clock, but they definitely heeded nature's rhythm and trusted their own senses. Working alongside their husbands in a supporting role, wives often operated within the rapid clock time of modernity. While both men and women moved constantly between home and the outside world, it was women who were tasked with running the home's front- and backstage areas. This included reception rooms with decorative chiming clocks, and kitchens where servants and mistresses followed taskoriented time. Only by understanding how bourgeois women experienced the passage of time in all the parts of their lives can we begin to gain a complete picture of how temporality operated in the nineteenth century. ${ }^{20}$ 


\section{Clock ownership, domesticity and the sense of time}

The concept of 'good' time management in a culture prizing orderliness and selfcontrol meant that clocks and watches signaled respectability. Contemporaries, however, knew that time was not uniform, as they contended daily with the coexistence of multiple measurements. As Corbin argues, 'At this period...to change place was also to change time.'21 In John Milne's 1899 survey Civil Time: Or, Tables Showing the Differences in Time between that used in Various Parts of the World and Greenwich Mean Time, he discovered that:

Lately the French Chamber of Deputies has passed a law which probably will be approved by the Senate, the text of which is "The legal time of France and Algeria is the time which is $9 \mathrm{~m}$. $21 \mathrm{~s}$. slow on Paris mean time."' Paris mean time is used by telegraphs and railways, but real railway time is about $5 \mathrm{~m}$. slower than this, or $55 \mathrm{~m}$. slow on Central European time. Also generally the clocks inside stations are $5 \mathrm{~m}$. slow on those outside, these latter showing Paris mean time. Some years ago there was a difference between town time and railway time, but this distinction between a local mean time and Paris mean time is disappearing, and it is only at places without stations that the former is sometimes observed. ${ }^{22}$

At the International Congress on Chronometry in Paris in 1900, French delegates engaged their international counterparts in discussion about the decimalization of time in the form of the ten-hour clock. This idea had been floated initially as part of the reinvention of time enacted by the French revolutionaries who introduced a ten-day week, and a calendar in which Year I was the start of the First Republic. The possibility that time could be measured in so many ways suggests that people still saw clock time as fluid and open to interpretation.

When historians define the temporality of modernity as relentlessly regular they are missing the point that the existence of clocks is not proof of their regularity 
nor of people's adherence to the information they provide. ${ }^{23}$ Contemporaries, however, took clocks as only one of many ways of marking time. They knew too that domestic clocks were less accurate than scientific ones. Hannah Gay has explored British accounts in which the tension between cultural commitment to rigid timekeeping and the limits of technology is clearly exposed, suggesting that while people may have desired strict accuracy, they continued to live without it. $^{24}$ Greater awareness of timekeeping in language, scheduling and public architecture were all part of the emergent middle-class's commitment to orderliness and self-control. ${ }^{25}$ Increasingly clock ownership was a sign of the cultural value placed on good time management practices. ${ }^{26}$ But in many ways it was a symbolic commitment rather than one that led to the abandonment of other ways of marking time. ${ }^{27}$

Post-mortem inventories offer evidence of the prevalence of clock and watch ownership in the nineteenth century. ${ }^{28}$ There cannot be absolute certainty as to whether some items have been removed from homes prior to inventory, and in certain cases - for example the death of a dependent minor — the inventory does not capture all the items in the home, but instead only those belonging to the deceased themselves. These methodological considerations aside, a survey of eighty-six inventories drawn from several parts of Paris over the years 1821 to 1891 offer a very strong indication that by the 1820s it was usual for Parisians to own timekeeping devices, and that this trend increased through the remainder of the century. This sample of inventories was arrived at by selecting inventories from notaries situated in diverse parts of Paris, in order to capture data about the bourgeoisie, as well as working-class and more elite households. This makes 
it possible to consider how middle-class attitudes towards time and timekeeping fitted into a wider picture of the increasing importance of clock ownership across the social spectrum. The dates of the inventories were selected to match the evidence from the diaries, while extending the reach slightly in order to understand how women's timekeeping might have been influenced by changing patterns of clock ownership through the century.

The ornate, decorative and costly nature of the clocks itemised in the wide range of inventories suggests that they served more than a simple measuring function. The 1824 inventory of Mme Foudinot's possessions included 'a pendulum clock of gray marble with two copper columns with chimes and enamel face marking hours and minutes on blackened wood pedestal.' The notary valued the clock at 100 francs, a significant amount in a home in which the entire contents, including furniture and clothing, came to 1570 francs. ${ }^{29}$ In 1843 M Mongalvy, mayor of the Second Arrondisment of Paris, died leaving behind a house full of beautiful possessions, including several clocks and watches the most valuable of which was 'a pendulum clock of black marble with golden figure containing 30 tiles two small torches and eleven florentine bronze candelabras.' valued at 800 francs. ${ }^{30}$

Post-mortem inventories were written room-by-room, offering clear indications about the structure of the house and the objects in it. Notaries labeled rooms based on their function, such as 'bedroom' or 'salon' or their location, for example 'a room on the first floor serving as salon lit by two windows onto the street $^{\prime 31}$ This means that the financial value of the item can be analysed alongside the value it was attributed through its place within the home. ${ }^{32}$ The eighty-six 
inventories that comprise this sample show clocks to have been placed primarily in public parts of the home, and in an almost equal number in bedrooms, but not in the more worklike parts of the home, and in particular not in kitchens. In Mme Josselin's home, on her death in 1885, there were two clocks in the dining room: a very expensive Louis XVI cartel clock (180 fr.), and a less expensive tableau horloge (80 fr.). Both clocks were wall mounted, and since two clocks are not necessary for keeping track of time, the choice to place both of them in the room was clearly aesthetic. ${ }^{33}$ Notaries, as well as describing very ornate clocks and watches, attributed relatively high monetary values to these items. In these ways, inventories create an impression of clocks being widely owned and esteemed and, especially among the middle and upper classes, serving a more symbolic than utilitarian purpose.

Of the eighty-six homes studied there are eighteen inventories that list no clocks. The frequency of clock ownership increased through the century, as did the overall number of clocks found in homes, but it does not seem to be the case that at any point clock ownership became entirely ubiquitous. A similar pattern can be determined with regards to the ownership of watches, which were owned by men more than by women, but in both cases remained a luxury item. Beyond the numbers, inventories are revealing for how items were categorized. Watches are listed alongside jewelry, which is generally valuable, but only in one instance, in 1843, with clothing, which is more utilitarian. ${ }^{34}$ Clocks, which are valuable, are listed alone, while other small objects are sometimes grouped together into lots. Notaries described people's more ornate clocks in meticulous detail, suggesting that they were valued for more than their price tag. Notaries-and possibly their 
clients-seemed in these ways to give timekeeping devices a special place at the intersection of useful tools, valuable possessions and decorative objects.

Patterns of clock placement that were apparent from the 1820s did not alter significantly during the rest of the century. There are 45 examples of homes with clocks in one or more bedroom; the next most likely room in which to find a clock was the salon, and there are twenty-three homes with one or more salons with clocks. Bedroom clocks were in the rooms of adult men and women, but none of the inventories include a clock in the bedroom of a son or daughter, and hardly any in servants' rooms. Bedroom clocks sometimes reflected the activities which might take place in that room, for example M Boulane's home, inventoried in 1824, had a clock in the shape of a woman holding a book, valued at 150 francs. ${ }^{35}$ After bedrooms and salons, clocks were most frequently placed in dining rooms, which occurs in twelve of the cases, while large houses also had clocks in billiard rooms and libraries, all parts of the house into which guests would be received. The placement of clocks in the homes of a wide range of Parisians suggests that clocks were used for organizing personal habits such as sleeping and eating, and social activities like visits and meals. They were not, however, present in the working spaces in the home. Only one inventory, from 1883 , listed a clock in the kitchen; this was in a very large house where several servants were employed and where there were six clocks spread over three salons, a bedroom and an office as well as in the kitchen. ${ }^{36}$ 
Men and women owned watches to keep track of time when they were away from clocks. Like clocks, watches were part of a culture of display and acted as indicators of personal adherence to the notion that respectability required order and efficiency. Inventories suggest that it was only adults who owned watches, pointing to the idea that children were not, in fact, in control of their own time, which, as we shall see, adolescent diarists were keenly aware of. The inventory evidence shows men owning watches more than twice as often as women: the inventories contain thirty-seven men's watches compared to seventeen belonging to women, while forty-six inventories don't refer to any watches. It is not necessarily the case that fewer women owning watches meant women were less bound by clock time. Rather, men's watches were an item of jewelry, which as John Styles has argued, may be more a matter of style than of function. ${ }^{37}$ Women, by contrast, had a wider array of jewelry with which to adorn themselves. Their diaries, though, suggest that women were perfectly aware of clock time, and equally comfortable noting time's mechanical measurement as they were nature's cyclical rhythms and patterns.

\section{Women's days: spending, saving and killing time}

The history of clock ownership in nineteenth-century France is the material evidence of a society committed to orderly timekeeping; time was a commodity not to be squandered. ${ }^{38}$ For bourgeois women, the enactment of this temporal order was more complex than it was for their male counterparts, who had an obvious division between work and leisure. For some scholars, the division of work time and leisure is an indication of the increasingly timetabled world of the modern bourgeoisie. Yet bourgeois women were largely excluded from that 
division, and often had to perform 'leisure' as work. For these women personal time was unstructured, so they had to impose order upon themselves. Alain Corbin has written about bourgeois women's domesticity and leisure, and condemned the ways in which they controlled the time of the domestic servants with whom they shared their homes. ${ }^{39}$ Beyond this, there has been too little research into the temporal practices women adopted to give shape to their days. One way to move beyond Corbin's impressionistic approach is by analyzing women's own diaries for what they reveal about women's sense of time and use of time.

Seven diarists provide the evidence in this paper for women's multifaceted temporal awareness and the complexity of bourgeois women's experiences of time and timekeeping. ${ }^{40}$ The diarists range from an impoverished adolescent living alone with her mother in obscurity in the provinces to the famous writer Amantine-Lucile-Aurore Dupin, better known as George Sand. ${ }^{41}$ Lucille le Verrier and Caroline Brame were both young bourgeoises who wrote diaries during the period of life in which their main occupations were being obedient and attracting a husband. ${ }^{42}$ Amélie Weiler and Marie-Edmée Pau were of a similar age to Brame and le Verrier when they kept their diaries. Living in the provinces rather than Paris each had fewer opportunities for amusement, leaving more time to fill with religious piety and domestic chores. Anne Madeleine Berthauld's diary differs from the others in form and also in content: rather than a series of dated entries narrating events as they unfolded, Berthauld's diary soon departs from the traditional format to become a sort of autobiography. Bertauld's diary shows the importance she placed on the interaction between her personal history, and 
the wider historical times her family had traversed. ${ }^{43}$ As one would expect, the diaries differ greatly in both scope and detail; some, like George Sand's, cover many years, while others are briefer. My access to them has also been varied, with many of the young women's diaries available only in edited published versions, while Sand and the Bourgeroise parisienne's diaries are manuscripts. ${ }^{44}$ There are, nonetheless, generalisation to be made about the uses of women's diaries for marking and organising time.

In attempting to understand how mechanical timekeeping shaped people's experience of temporality in early modern England, Glennie and Thrift counted the incidence of clock-time notation in the diaries of women and men. ${ }^{45}$ Corbin and others have been keen to point to the importance of diary-keeping as a feminine activity, and one that, in Corbin's words 'aimed to draw up a daily or periodic personal balance sheet, in the hope of limiting loss', placing it squarely within the bourgeois values of order, efficiency and economy. ${ }^{46}$ However neither Corbin nor Glennie and Thrift have read women's diaries for the sense of time's passage which their life writing contains. ${ }^{47}$ Philip Lejeune, by contrast, sees young women's diaries as offering insights both into their inner lives and-since diaries, like other written forms, fall into patterns and routines-into the cultural assumptions the diarists grow up in. ${ }^{48}$ In this way, diaries offer us an understanding of the ways in which the sense of time, as Norbert Elias has argued, is a form of knowledge passed on between generations. ${ }^{49}$

Diaries were a way of spending and measuring time, and the ways in which French women wrote about their time in the nineteenth century were marked by 
their belief that time was scarce and fleeting. ${ }^{50}$ Dated entries gave shape to life as it unfolded, and also acted as a useful aide-memoire, when keeping track of reciprocal relationships around gift giving, letter writing and paying and receiving visits. George Sand and the anonymous Bourgeoise Parisienne, married women with busy lives, used the same kind of tall, thin notebook, with printed dates and lined as if for the keeping of accounts. These books, as objects, are telling of a culture in which the desire to keep track of time had been seized on as a commercial opportunity by printers, whose products added material evidence that time was a measurable resource. ${ }^{51}$ In them, women measured their time and kept a note of religious and secular life, including church attendance, food preparation, and attendance at social events.

Women measured time as a scarce resource, but also as a repetitive series of routines and patterns which overlapped with nature's own rhythms. 52 The Bourgeoise parisienne, for example, combined a repetitive daily routine shared with a small circle of acquaintances, with the annual marking of the anniversary of her mother's death, and reflections on momentous political changes she, along with her family, experienced. ${ }^{53}$ George Sand's moods, as recorded in her own words, were deeply entwined with the changing of the seasons and of fluctuations in temperature, something Alain Corbin argues was true of people in the nineteenth century more broadly. ${ }^{54}$

In adulthood the separation of home and work appeared to separate women's role and women's time from that of the men they married. ${ }^{55}$ For the journalist Chatillon Plessis, this separation represented 'truth and beauty': 'To men, 
exterior work. To women, indoor work...For as long as we seek a different solution to societal or personal wellbeing, we will have only misery. ${ }^{56}$ Yet many women, including the Bourgeoise parisienne, had to take on men's work, and did so with little difficulty. The Bourgeoise parisienne sometimes took over her husband's business when he was sick, finding new tenants, collecting rents from existing ones, paying bills and negotiating with creditors. ${ }^{57}$ Her experience provides an example of how easily women moved in and out of their domestic world.

Alongside these tasks, the Bourgeoise parisienne was a typical woman of her class, whose daily activities consisted of paying visits, receiving callers, writing and receiving letters, hosting and attending dinners and parties and making jams and preserves, as well as keeping track of her husband's and son's affairs. In this, she acted as the family's timekeeper. Whether they were well or ill, her husband Etienne and their son Edmond benefitted from her skills in keeping track of time, and managing family affairs, and she made notes to this effect in her diary. In 1870-71, she wrote every day about the state of her husband's health. She also wrote about her son. Almost daily she noted 'Edmond va à son étude'. She noted every Thursday that he had attended his music lesson, and wrote about all the parties he went to, who he dined with, and which friends visited him at home. Sometimes, when Edmond's routine varied, his mother's notations were more detailed, such as on Monday February 28, 1870, when Edmond stayed at a party until 3:30 in the morning, and then brought two friends to sleep over, and the following day, when she wrote: 'Edmond wakes up late, Joseph and Ludovic leave at 9:00, after drinking a cup of chocolate.'58 On another occasion, the whole 
family went out together, and the bourgeoise Parisienne kept careful track of the time they spent:

Edmond arrives at 6:00 to get dressed and the three of us leave to dine at Mme [Broul] good dinner, 10-...Mme Leon sings us two very good chansonettes-Edmond sings. We return home at 11:15.59

Every bourgeois girl and woman was expected to take part in rounds of visits, and Le Verrier was clear that this could be a pleasure but also, at other times, a burden, signaling the way in which visits constituted unpaid female labour taking place behind closed doors while men went out to work. ${ }^{60}$ Anne MartinFugier has pointed to the importance of these visits for the marriage market, an economic system central to the perpetuation of bourgeois respectability. But beyond the marriage markets, these visits were both a way of spending and of killing time, for women stuck in a moral universe in which time was precious while one of the principal aims was ostentatiously to enact leisure, a point which in itself highlights the inadequacy of the work-leisure divide for historians aiming at a gendered understanding of the temporal order of modernity.

From a young age Marie-Edmée Pau worried about time and how to spend it: 'I am fourteen today, and I do not want to let this day pass without noting my reflections and the resolutions I have made.' 61 As a solemn and devout Christian, some of her time preoccupation came from her devotional reading, and she made reference to books such as Charles Sainte-Foi, Heures serieueses du jeune age. ${ }^{62}$ As the title suggests, this book was a guide to spending time wisely as a young Christian; devotional reading was a respectable pastime, and elsewhere has been 
argued to show evidence of the overlapping of industrial and ecclesiastic temporalities in the nineteenth century. ${ }^{63}$ Pau's preoccupation with the rapidity of time led her to want to maximize her waking hours, which she did by waking up at 5:30, to accompany her mother to first mass, in order to have a longer day afterwards. ${ }^{64}$ She worried, also, about the inevitability of death. When her grandfather died, Pau wrote: 'life is so short and time so fast that it will soon close the space that separates us from you.' 65 The following year, she wrote: 'I see each day that fades as a friend who I will never see again...This year I am fifteen, but next year I will be sixteen...Once these days go by life will pass quickly for me, and death will not be long in coming.'66 In December of 1860 she wrote that there was 'another month less for me on this earth, one step closer to the grave.'67

Other young diarists, like Pau, were explicit about their time awareness, and their feelings-positive or negative-about daily life being strictly timetabled. Amélie Weiler railed against the need for order imposed through chores, writing:

What do I have to write about, apart from that I am on my feet all day, that I cook, sweep and dust, and after having slaved all day, I am scolded for the smallest oversight. 68

Weiler was frustrated to live in an environment in which a girl's time was highly structured, but where she had no choice about the activities that filled her time. ${ }^{69}$

For Lucile le Verrier, time awareness lay in part in the anticipation of future events, and the sense of sadness when they passed: 'Here it is soon passed, this 
much anticipated new year's day.' 70 She was also keen to follow a timetable and establish a routine, which she set out for herself in her diary in 1867:

I normally wake up at 7:30 and work until 10:30. Then I arrange my hair and we have breakfast; I have free time from 11:30 to 2:00; then work until 6:30, when we dine. In the evening I study my catechism and go to bed around 11:00.71

Perhaps this timetable was a symbol, to her, that she was spending her time well and not wasting it. But the timetable was not an indication of le Verrier's slavish devotion to the ticking clock. Indeed as her diary made clear, very few of le Verrier's days followed exactly the set pattern, since, for example, on Thursdays and Sundays she attended mass, while on many other days she visited friends or received visitors at home. Like Marie-Edmée, Lucile wanted a schedule as a way of making her timekeeping fit with the pattern valued by the adults around her. ${ }^{72}$ But like many other girls and women of her age, she had a great deal of time on her hands, with no need to earn a living, and little independence in choosing how to spend the hours of the day.

Anne Madeleine Berthauld also used her diary to make sense of her place in time. Berthauld, with one Catholic and one Protestant parent, was intrigued by her family history, describing herself as having 'Jewish blood in my veins, Protestant blood and Catholic blood. ${ }^{73}$ Berthauld's diary was not part of a daily routine, but she used it to set out and reflect on her family and personal history. In the first few pages of her undated diary, she related her belief that she was distantly related to Napoleon Bonaparte, and that her family had lost land in St Domingue due to the Revolution there. She described her maternal grandfather's close friendship with the poet Lamartine, and her mother's first marriage, aged 18, to a 
Mr Camburini, with whom she had three children in three years, going on to state that 'at twenty-six, [my mother] was a widow, Monsieur Camburini, having done badly in business and then committing suicide by shooting himself in the heart.'74 Berthauld's mother then devoted herself to her children, until she married the eldest boy's tutor, Auguste Berthauld, in 1880, giving birth to Anne Madeleine the following year. ${ }^{75}$ In Berthauld's account, History writ large merged with family lore and the small and large events of her own. In this way she resembles the Bourgeoise parisienne, whose diary spanned the years of the Franco-Prusssian war, the fall of the second Empire, and the siege of Paris. When she, along with many of her circle, left the dangers of Paris for the greater safety of the provinces, her husband and son stayed behind. There followed a period of anxiety, as letters often could not get through. When they did, as on the $14^{\text {th }}$ of January 1871, she wrote 'I received a letter from Edmond written on the 10th, he is so good this dear child, he does everything he can to reassure me about the bombing of Paris... they are well thank God.'76 These anxious musings were intertwined with more mundane notations about the routines of her daily visits and food preparation. Both Berthauld and the Bourgeoise were at ease writing in the same tone about major political upheavals and minor domestic concerns and social interactions.

George Sand's diaries are the most extensive of any of the women's studied in this paper, covering the years 1852 to 1876, the year Sand died. She differed from the other women in obvious and significant ways, as an independent woman who made her own money by writing, as well as living in the public eye, and has been seen as influential culturally and - to a more limited degree- 
politically. Not always happy to be identified as a feminist, Sand chose a masculine pen name in order not to be thought of as a woman writer. ${ }^{77} \mathrm{Her}$ diaries, though, reveal most about the ways that women lived within and beyond the public sphere, precisely when we look beyond her public persona and see her in her domestic activities and concerns.

March 1852, being in many ways a perfectly typical month, reveals many of the characteristics of Sand's intimate writing. Sand wrote about herself in the third person, referring to herself frequently as 'Madame' when describing sleeping patterns, and health concerns. Thus: 'Madame is ill,' on March twenty fourth; and 'Madame woke 9 o'clock—she left at $1 / 4$ to 10 to go to Mme Sevigny's,' on March thirty-first. ${ }^{78}$ Sand was very conscious of time, and seems likely to have had clocks in both her bedroom and salon given her notations about sleeping and waking times as well as the times that she and her visitors came and went from the house. In this, as in her preoccupation with health concerns, Sand's diaries were like those of other women, who also used their diaries to keep track of daily events, comings and goings, and the reciprocal responsibilities of visiting and letter writings.

Sand did differ from other women in the degree of independence she appears to have had, and the amount of work she did every day, often in the evening after the household had retired for the night. A day in Sand's life might look something like this entry from April 8, 1852:

Madame is well. Lunch with Nohaut. visit...-Madam goes for a promenade-she goes up to work, we dine at 4 -we go walking. The 
weather turns bad-we go home, play dominoes-read the newspaper-at 10:30 we go up to bed.-Madame works. ${ }^{79}$

Perhaps the late working, though, was a concession to the need to be present in the life of the household during the daytime rather than a sign of her independence.

Ten years later, Sand's diaries were much the same: 'Still freezing. Madam slept well...this morning she is not in very good humour.'80 Sand continued to make daily notes of the weather, her health, and how she slept, which creates a sense that though time passes it also remains the same. Often, the activities which this celebrated and busy women chose to record were the most ordinary ones, which she had in common with other women of her class, for example on February tenth, when she described walking in the garden, visiting an acquaintance, and writing letters. ${ }^{81}$ And like the Bourgeoise parisienne, Sand interspersed these personal notes with observations of external events, such as 'they have started to tear down the library.' 82 Sand's timescape was public and private, following a Lefebvreian rhythm of repetition punctuated by difference. ${ }^{83}$

While Martin-Fugier, Corbin, Smith and others have defined bourgeois women's lives in the nineteenth century as entirely domestic, and their sense of time as biologically determined, and outside of modernity, women's own diaries tell a different tale. Indeed, in combination with evidence of the extensive presence of clocks in domestic space, women's diaries suggest a complex and multi-faceted sense of time. Middle-class women were their families' time managers, and looked after both nature's cycles, and modernity's ticking-clock time. As we shall 
see, in the kitchen, where clocks were not normally present, women were presented with expert advice that was reliant on this complex sense of time, and where clock time was interspersed with task-oriented and sense-based timekeeping.

\section{Time discipline, domestic management and cookbook instructions}

Cookbooks and domestic advice manuals were written by 'experts' intent on sharing their assumptions about women's roles with women themselves. Designed around the daily domestic routine, these manuals can show us contemporary assumptions about women's timekeeping regimes. ${ }^{84}$ These normative assumptions about bourgeois women's time awareness and their ability to manage domestic time reveal contemporary notions of time. Anxiety about time was present in a variety of domestic manuals, highlighting a general concern about the risks to family stability if wives and mothers were to waste precious time. In advice about cooking-in recipes for example-time came to the fore because of the time-sensitive nature of cooking. Food preparation is comprised of three temporal elements: the cyclical rhythm of nature which makes different foods available at distinct moments in the year; regular mealtimes as a way of punctuating the day; and the coordination of cooking times of a range of dishes so that they arrive at the table ready to eat and at the appointed moment in the order of the meal. Food's place in the march of history, the progress of civilization, and the conquest of nature by technology are all concerns betrayed by writers in their various attempts to advise women on how to maintain a balanced approach to their traditional time in an increasingly mechanical world. 
Coming out at regular intervals, periodicals could be more precise about seasonality than many cookbooks, tapping into cyclical as well as linear time, for example in recipes specifically for Lent in the spring. ${ }^{85}$ First published in 1893 , Le Pot-au-Feu used the premise that there were already sufficient books in circulation to opt out of publishing extensive menus. Instead, they chose to '[draw] our readers' attention to the products of the moment, and indicate two or three recipes that allow these to be used in the best ways possible. ${ }^{86}$ Advice about food and season was directed at urban rather than rural housewives, and was a tacit commentary on the rupture with nature's cycles caused by modernity. In this way, the importance placed on seasons shows that while linear time might control business and public life, in the domestic sphere there remained an overlapping commitment to earlier understandings of time.

Seasonality was a central concern of the author of the Bréviaire du gastronome from 1828. This book addressed the masculine world of fine dining, with women cast as the purveyors of the fine food enjoyed by men. It was wives more than their husbands who needed to know that, for example, June was the month in which to enjoy 'Beef, veal, mutton...pigeon, cod...green beans, cucumbers...melons, red berries' ${ }^{87}$ A history of dining was followed by a 'nutritional calendar' devoted to instructing the reader in nature's cycle as it pertained to the pleasures of fine dining. Readers were enjoined to "meditate on it often, and even to learn it by heart.'88 Yet devotion to the concept of seasonality did not entail the abandonment of the benefits technology offered in making foods available all year round. Monthly sample menus included both in- 
season and out-of-season items; June, for example, included several of the seasonal items listed above alongside other delicacies like stuffed turbot fillets and lambs tongues in mayonnaise. ${ }^{89}$

The anonymous author of the Manuel des bons maitres et des bonnes servante, published in 1884, offered advice starting from infancy with the mother modeling good behaviour to her baby by praying in front of its crib. ${ }^{90}$ Later, in adolescence, acknowledged as a difficult period, the father was to take a more active role, 'saying prayers together with the whole family, going to mass on Sunday, and taking communion....at important holy days.'91 These good religious routines had to be matched by equally important good behaviour around food:

Gourmandize...flaw of the era that needs to be nipped in the bud as soon as it makes an appearance. The best portion will go to the father who works; yet he will be reasonable enough not to take too much advantage of this...the mother will make...healthy, fortifying and varied meals. No sensuality. ${ }^{92}$

The book included a chapter about training girls in proper ways of spending their time. This kind of training may have been at play when Pau became convinced of the need to rise early to pray and clean, and when Le Verrier set herself a strict timetable she never quite adhered to. In the Guide des bons maîtres, mothers were urged to begin training a girl from age eight to rise early, and embark on a lengthy routine of grooming and housework which included washing her hands and face upon waking, and completely cleaning and dusting her bedroom after breakfast every morning. ${ }^{93}$ In adolescence the domestic routine would become lengthier for the daughters of parents who followed the book's advice to take a girl out of school so that her mother could train her 'entirely for family life.'94 Such training included helping to dress younger 
brothers and sisters, as well as cleaning and mending. While she was still young enough to benefit from education, the authors advocated a mixture of intellectual and manual work, according to the following formula:

We cannot be explicit about time, as meals are not eaten at the same time everywhere. But it is necessary that each day contain at least six hours of intellectual work and two hours of manual work, interrupted with short breaks of half an hour; three will suffice, one after each meal. ${ }^{95}$

But when she was not working, a girl should not be engaging in the same noisy play as her brothers, but rather playing with dolls alongside her sisters or friends. ${ }^{96}$

The strict adherence to daily routines advocated in this kind of advice literature alerts us to the way that modern timekeeping had infiltrated the home and was wound up inextricably with moral precepts of Christianity and bourgeois respectability. Various historians have pointed out the ways in which routines emerged around keeping the house clean, which provided a repetitive and rhythmic cadence to household chores. This cleaning cycle included weekly dusting of shelves and cupboards and monthly polishing of all kitchen utensils. ${ }^{97}$ The paradox for bourgeois women was clear: how can you signal adherence to a strict time discipline while also living out the leisure that is your class badge of honour?

The paradox experienced by bourgeois women who had to spend their time frugally, while also ostentatiously performing their leisure was apparent to cookbook writers who struggled to find the right voice with which to address 
mistresses and their servants. Alain Corbin writes that '[p]aradoxically, the woman of the leisured classes was not content to be the showcase of her man'.98 Such a woman, instead, 'felt the need to justify the utility of every moment ... as if competing with the precious and measured time of her husband, caught up in the social fray.' 99 Yet where Corbin assumes a choice made by women to seem to work, cookbook writers recognized that within the bourgeoisie were many women who had to both carry out household chores and perform their leisure. In the Nouveau Manuel de la Cuisinière Bourgeoise et Economique, published c. 1850 by the pseudonymous 'ancien Cordon Bleu', there were chapters directed explicitly to servants, outlining domestic routines as well as the importance of pleasing one's employers. ${ }^{100}$ But further on in the book a chapter on 'The Honours of the Table' was clearly for the benefit of hosts and hostesses of dinner parties. ${ }^{101}$ Less clear was the intended audience for the many recipes that took up the pages between these sections. Behind the ambiguity was the hidden fact that many women did their own cooking, while pretending to have more domestic help than they could actually afford. Thus women's time was sometimes split between domestic labour and the appearance of leisure, and cookbook writers were aware of this, and of the need to divide their advice accordingly.

Changing vocabulary in reference to time in nineteenth-century cookbooks has created a misleading impression that clocks were an important kitchen utensil. ${ }^{102}$ Sara Pennell suggests that the early modern invention of the built-in stove offered greater temperature control than an open fire. ${ }^{103}$ Yet even with the introduction of gas cookers in the later nineteenth century, temperature 
regulation was inexact, and Maitte and Terrier are right to suggest that clocktime vocabulary in the nineteenth century was probably used to refer to taskbased time measurement, which is consistent with the finding that most homes did not have a clock in the kitchen. ${ }^{104}$ Beginning to appear as early as the seventeenth century, clock-time notations in recipes might seem to indicate the incursion of mechanical time into the home. However the cooking technologies of the time, for regulating heat for example, were rudimentary at best. To say that something would take ten minutes to cook could never have been more than a vague indication, since it was well known that different ovens reached different heats, and that external factors such as the weather could alter cooking times.

The measurement of time in the kitchen, for the writers who offered domestic advice to bourgeois women, interwove clock time with sense time. In $1822 \mathrm{~A}$. T. Raimbault, whose pseudonym was 'Homme de Bouche' offered a recipe for poached egg potage. In this recipe there was no overall cooking time offered, but there was advice to add some pepper 'a quarter of an hour before serving', combining an assumed knowledge about overall cooking times, with a more clock-based sense of the connection between cooking time and serving time. ${ }^{105}$ Raimbault's recipe for 'Coeur de Boeuf à la Poivrade' involved marinating the beef for 'several days', then grilling it and serving it with sauce, without instructions about timing, even with regard to the number of days to marinate the beef. ${ }^{106}$ Yet in the same book, the recipes for 'Fraise de Veau' and 'Epaule de Veau à la bourgeoise,' were more precise, suggesting two and three hours of cooking time respectively ${ }^{107}$ The author made clear assumptions about women's prior knowledge, and ability to perceive when beef was grilled and ready to 
serve, for example, without needing to glance at the clock. Whether or not the recipes that were more precise about time suggest a parallel assumption about access to clock time during cooking is less clear.

Fraise de Veau, a popular cut, appeared in many cookbooks, all with slightly different instructions hinting at the diversity of approaches to measuring time in the kitchen. An 1805 cookbook, La Cuisine Elementaire et Economique, Propre a toutes les condition et tous les pays, offered a very simple recipe with no advice about times or amounts: 'boil your fraise de veau in water, and when it is ready, it is eaten with vinegar.'108 In 1826, the author of the Nouveau Dictionnaire de Cuisine, D'Office et de Patisserie, had a slightly more elaborate preparation, which specified boiling the fraise de veau in water for a quarter hour, cooling it in cold water, and then cooking it again au blanc, that is in water with flour and lemon juice. For the second period of cooking there was no indication of the length of time required. ${ }^{109}$ The same recipe, now referred to as 'Fraise de veau a la française,' also appeared in the ancient Cordon Bleu's mid-century cookbook, addressed especially to the bourgeoisie. As in the Nouveau Dictionnaire, the instruction was to boil for a quarter of an hour, cool, then cook again, but for an unspecified length of time. ${ }^{110}$ Another book of recipes for the bourgeoisie, this one published in 1884, had a recipe for 'fraise de veau frites' which required frying slices of marinated veal until they were 'a nice colour.'111

The same loose and flexible approach to timekeeping persisted throughout the nineteenth century. The recipes in Urbain Dubois's successful La cuisine de tous les pays, published in 1899, show little had changed over the course of the 
century when it came to the multi-layered temporality of the kitchen. Dubois was prolific, widely read, and wrote explicitly for respectable bourgeois women. In $L a$ cuisine de tous les pays, a recipe for 'Queue de Merlan [whiting] à la mode de Cherbourg' contained very precise instructions to: 'cook the fish for 8 to 10 minutes, on a high heat.'112 But two pages later, another recipe, for 'Tranche de Merlan, à la marseilleise' had no specific timings. Instead readers were instructed to 'cook them on a good heat, turning them...once they are well done, drain them,' assuming that a woman, or her cook, would know how long this process should take without recourse to the clock. ${ }^{113}$

\section{Conclusions: towards a history of women's modernity}

Whether or not they watched the clock while they cooked, women clearly lived in homes where clocks were prized objects, prominently on display in frontstage spaces like the salon or the salle à manger. Women owned watches, too, and made references to clock time in the diaries many of them kept, which tracked the passage of time in all sorts of personal and public ways. Whether tacitly or explicitly, too many historians have posited the history of modernity as something that happened outside the home, and therefore excluded bourgeois women. Thinking about temporality, we can see that women, in fact, had a varied and complex experience, in which modern, linear time overlapped with more traditional, cyclical ways of measuring. Looking beyond sources explicitly about time to ways in which temporal regimes shaped daily life this paper has made clear the extent to which women were active participants in clock-based, modern temporal regimes. By focusing on women's timekeeping practices, and women's own expressions of them, this paper argues that modern temporality was more 
multifaceted and complex than many historians have heretofore allowed.

Women's role as family timekeepers, and their ability to move between public

and private timescapes, allowed them to negotiate the intersection between

shared clock time, and more local, idiosyncratic timekeeping practices that

persisted through the nineteenth century. By acknowledging that cookery and

domestic advice manuals employed complex forms of temporal language, this

research has made a significant contribution to the history of timekeeping, by

extending our understanding of what can constitute a source of knowledge about

temporal practice.

${ }^{1}$ Journal d'une Bourgeoise parisienne, April 4, 1871, Bibliothèque de L'Hôtel de Ville (BHdV) MS 32.

${ }^{2}$ Bourgeoisie parisienne, May 24, 1871.

${ }^{3}$ Bourgeoise parisienne, June 5, 1871.

${ }^{4}$ If not for the war and siege, her diary would likely not have been preserved in the Hôtel de Ville library's collection.

${ }^{5}$ Alain Corbin has written about the bourgeois love of accounting, for money and in more intimate matters. In this sense, the Bourgeoise Parisienne's diary can act as a time management device. See A Corbin Time, Desire and Honour: Towards a History of the Senses, J. Birrell trans, Cambridge, UK: Polity Press, 1995, pp. 8-9.

${ }^{6}$ For examples of new directions in the study of women and gender in modern France see J. Burr Margadant ed., The New Biography: Performing Femininity in Nineteenth-century France. London: University of California Press, 2000; W. G. Pooley, "Independent Women and Independent Body Parts: What the Tales and Legends of Nannette Lévesque Can Contribute to French Rural Family History," Folklore 121.2 (2010): 190-212; C. A. Bouton, 'Reconciliation, Hope, Trust and Instability in July Monarchy France,' French Historical Studies, 2012, 35 (3): 541-575; S. Horowitz, 'The Bonds of Concord and the Guardians of Trust: Women, Emotion, and Political Life, 18151848,' French Historical Studies, 2012, 35 (3): 578-603; D. Z. Davidson, France after Revolution: Urban Life, Gender and the New Social Order, 2007; R. Rodgers, From Salon to Schoolroom: Educating Bourgeois Girls in Nineteenth-Century France, 2005; J. E. Pedersen, '"Speaking Together Openly, Honestly and Profoundly": Men and Women as Public Intellectuals in Early-TwentiethCentury France, Gender \& History, 2014, 26 (1): 36-51. This research is not limited to the French case. See for example: D.S. Shields and F. J. Fredrika, 'The Republican Court and the Historiography of a Women's Domain in the Public Sphere,' Journal of the Early Republic, 2015, 35 (2): 160-183; S. Steinbach, 'Can we still use 'Separate Spheres'? British History 25 Years After Family Fortunes,' History Compass, 2012, 10 (11): 826-837.

${ }^{7} \mathrm{~J}$. Le Goff, Time, Work and Culture in the Middle Ages, A. Goldhammer trans. London: University of Chicago Press, 1980; E. P. Thompson, 'Time, Work-Discipline, and Industrial Capitalism,' Past and Present, No. 38 (1967): 56-97.

8 See also G. Dohrn-van Rossum, History of the Hour: Clocks and Modern Temporal Orders, T. Dunlap trans, London: University of Chicago Press, 1996; J. Fabian, Time and the Other: How Anthropology Makes its Object, New York: Columbia University Press, 1983; E. Grosz, The Nick of Time: Politics, Evolution and the Untimely, London: Duke University Press, 2004; H.-J. Voth, Time and Work in England, 1750-1830, Oxford: Clarendon Press, 2000.

${ }^{9}$ L. Tiersden, Marianne in the Market: Envisioning Consumer Society in Fin-de-Siècle France, University of California Press, 2001, pp. 15-54; H. Cunningham, Time, work and leisure: Life 
changes in England since 1700, Manchester University Press, 2014 is a good example of how recent scholarship undermining the public/private dichotomy has failed to make inroads into thinking about the social history of modern time. Others have noted the neglect of gender in temporality research, and the neglect of time as a concept in gender studies. See West-Pavlov, p. 7. 10 See S. Horowitz, 'The Bonds of Concord and the Guardians of Trust: Women, Emotions, and Political Life, 1815-1848,' French Historical Studies, 35 (3): 577-603; Lindsay A. H. Parker, Writing the Revolution: A French Woman's History in Letters, Oxford: Oxford University Press, 2013. 11 Though he overemphasises the break between tradition and modernity, G. T. Morran makes it clear that in the sixteenth century cyclical and linear concepts of time did overlap. See 'Conceptions of Time in Early Modern France: An Approach to the History of Collective Mentalities,' The Sixteenth Century Journal, Vol. 12, No. 4 (Winter, 1981), pp. 3-19. On women's understanding of time as seasonal and cyclical see B. G. Smith, Ladies of the Leisure Class, pp. 96107.

12 See for example M. Shaw, Time and the French Revolution: The Republican Calendar, 1789-Year XIV, Woodbridge, Suffolk: The Royal Historical Society, the Boydell Press, 2011, p. ix, 17, which assumes a clear break between fluid early modern time, and fixed nineteenth century time. ${ }^{13}$ See for example R. West-Pavlov, Temporalities, London: Routledge, p. 7; M. D. O'Hara, 'The History of Time in Colonial Latin America,' History Compass 11/1 (2013); J. Terni, 'The Omnibus and the Shaping of the Urban Quotidian: Paris, 1828-60' Cultural and Social History, 11/2 (2014): 217-242; M. Esbeter, 'Designing Time: The Design and Use of Nineteenth-Century Transport Timetables,' Journal of Design History, 22/2 (2009): 91-113; P. Corfield, Time and the Shape of History, London: Yale University Press, 2007.

${ }^{14}$ C. Maitte et D Terrier, 'Conflits et resistances autour du temps de travail avant l'industrialisation (XIVe-mi-XIXe siècle), Temporalités: Revue de sciences sociales et humaines, 16, 2012, p. 6.

15 The concept of temporal networks is taken from P. Glennie and N. Thrift, Shaping the Day: A History of Timekeeping in England and Wales, 1300-1800, Oxford: Oxford University Press, 2009. 16 This oft-reprinted and influential essay first appeared in R. Bridenthal and C. Koonz eds., Becoming Visible: Women in European History, Houghton Mifflin, 1976.

17 J. Kristeva,'Women's Time' A. Jardine and H. Blake Trans. Signs 7 (1) 1981: 13-35

18 B. G. Smith, Ladies of the Leisure Class: The Bourgeoise of Northern France in the Nineteenth Century, Princeton: Princeton University Press, 1981, pp. 95-101.

${ }^{19}$ R. Felski, Doing Time: Feminist Theory and Postmodern Culture, London: New York University Press, 2000.

20 The temporality of modernity was of great interest to twentieth-century theorists of modernity, who were not, however, interested in women's experiences. See for examples G. Simmel, The Metropolis and Mental Life' 1903.

21 Corbin, p. 1.

22 J. Milne, Civil Time: Or, Tables Showing the Differences in Time between that used in Various Parts of the World and Greenwich Mean Time, In The Geographical Journal for February 1899, p. 7.

${ }^{23}$ In his wide-ranging study of temporality West-Pavlov posits the Enlightenment as a turning point in the emergence of modern time, but this does not take into account the limits of technology in the late eighteenth century. See West-Pavlov, p. 6.

${ }^{24}$ See for example the proceedings of the International Congress on Chronometry, Paris, 1900; Also H. Gay, 'Clock Synchrony, Time Distribution and Electrical Timekeeping in Britain, 18801925,' Past and Present 181(2003) 107-40.

25 R. Rich, "'If you desire to enjoy life, avoid unpunctual people": Women, Timetabling and Domestic Advice, 1850-1910,' Cultural and Social History 12 (1).

${ }^{26}$ For an argument on the connection between clocks and the rise of the middle class see for example J. Frykman and O. Löfgren, Culture Builders: A Historical Anthropology of Middle-Class Life A. Crozier trans. New Brunswick, 1987; J. Kocka, "The Middle Classes in Europe". The Journal of Modern History 67 (4). University of Chicago Press: 783-806; R. Rich, Bourgeois Consumption: Food, Space and Identity in London and Paris, 1850-1914, Manchester University Press, 2011. ${ }^{27}$ H. Gay, 'Clock Synchrony, Time Distribution and Electrical Timekeeping in Britain 1880-1925'; J. Styles, 'Time Pieces: Working Men and Watches,' History Today, Vol. 58, No. 1, 2008, p. 44-50. For a similar analysis of the significance of watch ownership in the United States see A. McCrossen, 'The "Very Delicate Construction" of Pocket Watches and Time Consciousness in the Nineteenthcentury United States,' Winterthur Portfolio 44.1 (2010): 1-30.

28 The most extensive and rigorous use of post-mortem inventories in French History probably remains A. Pardailhé-Galabrun, La Naissance de l'intime. 3000 foyers parisiens, XVIIe-XVIIIème 
siècles, Paris: Presses Universitaires de France, 1998. For other instances of historians' use of post-mortem inventories, see for example: C. Fairchilds, 'Marketing the Counter-Reformation: Religious Objects and Consumerism in Early Modern France,' in C. Adams et al eds. Visions and Revisions of Eighteenth-Century France, The State_University of Pennsylvania Press, 1997; S. Domont, «Les objets religieux dans les inventaires après décès à Marseille (1539-1629) ", Rives méditerranéennes [En ligne], Jeunes chercheurs, mis en ligne le 14 août 2014.

${ }^{29}$ March 1824, M Fourdinout (MC/ET/LXX/917).

${ }^{30}$ February 1843, Mr Mongalvy MC/ET/CI/1144).

31 October 1845, Mme Dupuy (MC/ET/LXXV/1183).

${ }^{32}$ Historians of material culture have begun to consider the place of objects within the home, but have not given particular attention to clocks as being at the intersection of culture and technology. See for example B. L. Herman, 'Tabletop Conversations: Material Culture and Everyday Life in the Eighteenth-Century Atlantic World,' in J. Styles and A. Vickery eds., Gender, Taste, and Material Culture in Britain and North America, 1700-1830, pp. 43-50; A Vickery, Behind Closed Doors: At Home in Georgian England, pp. 263-5.

${ }^{33}$ April 1885, Mme Josselin (MC/ET/CXV/1630).

34 Jan. 1843 Mme Pipot (MC/ET/CI/1143-1144).

35 March 1824, M Boulane (MC/ET/LXX/971).

${ }^{36}$ May 1883 M Jules Charles Michel-Greyveldinger (MC/ET/VII/839).

${ }^{37}$ John Styles, 'Time piece: Working men and watches,' History Today (Vol.58, no.1), 44-50.

38 This idea of time as commodity is at the heart of Corbin's argument in Time, Desire and Honour. The idea of the European bourgeoisie as 'Clock Watchers' is explored in Frykman and Löfgren, Culture Builders, while D. Landes has argued that superior time discipline was what allowed Europe to gain the global hegemony it enjoyed in the modern period. See Landes, Revolution in Time: Clocks and the Making of the Modern World, Belknap Press of Harvard University, 1983. ${ }^{39}$ A. Corbin, Time, Desire and Honour: Towards a History of the Senses, J. Birrell trans, Cambridge, UK: Polity Press, 1995, pp. 6-7.

40 While various scholars have made use of diaries in studying French history, Anne Martin-Fugier points out that the diaries of respectable women are particularly difficult to locate, as the majority of them were likely to have been destroyed by the writers themselves or by their descendants. See La Bourgeoise, p. 13. This point is also made in R. Rogers, 'Schools, Discipline and Community: Diary-Writing and Schoolgirl Culture in Late Nineteenth-Century France,' Women's History Review, 1995, 4 (4), p. 527.

41 Journal d'une Bourgeoise Parisienne, BHdV MS 31/32; Journal de Anne Madeleine Berthault, Paris, 1900, Biblioteque Marguerite Durand, MS 322; Le Journal intime de Caroline B. Enquête de Michelle Perrot et Georges Ribeill, Paris: Archives Privées, Montalba, 1985; M.-E. Pau, Le Journal de Marie-Edmée, Intro de M. Antoine de Latour, Paris: Plon, 1876; G. Sand, Papiers de George Sand III-XXVII; L. le Verrier, Journal d'une jeune fille Second Empire. Zulma, Calman-Levy, 1994; A. Weiler, Journal d'une jeune fille mal dans son siècle (1840-1859), Strasbourg: Nuée Bleue, 1995. $42 \mathrm{P}$. Lejeune, introduction to Weiler, Journal d'une jeune fille mal dans son siècle, p. 3. This fixation on marriage is equally apparent in Le journal intime de Caroline B. and le Verrier, Journal d'une jeune fille Second Empire.

43 David Gross argues that there is an interaction between personal sense of time, and the sense of longue durée time people use to make sense of their place in the world. See 'Temporality and the Modern State,' Theory and Society Vol. 14, No. 1 (Jan., 1985), pp. 54-5.

44 Scholars have pointed to the great diversity of writings which can be described by the term diary, arguing for their hybridity, and that they sit uneasily between history and literature. For a lengthier discussion of this see I. Paperno, "What Can Be Done with Diaries?" The Russian Review, 2004, 561-3. See also H. Beattie, "Where Narratives Meet: Archival Description, Provenance, and Women's Diaries," Libraries \& The Cultural Record 44 (1): 82-100.

45 Glennie and Thrift, pp. 196-212.

46 Corbin, p. 9.

47 For a more detailed discussion see Paperno, p. 565. There is an increasing scholarly literature on life writing as historical source. See for example M Lyons, 'Love Letters and Writing Practices: On Ecritures Intime in the Nineteenth Century,' Journal of Family History, 1999, 24 (2): 232-239; M. Sonnet, 'L'émoi des demoiselles en voyage. Du voyage dans quelques journaux intimes de jeunes filles du XIXe siècle,' Genre \& Histoire, 2011, 9.

${ }^{48}$ Philippe Lejeune is the foremost expert on diaries, including the diaries of young women, of which some are considered here. See for example P. Lejeune, On Diary, J. D. Popkin and J. Rak eds. 
K. Durnin trans., University of Hawai'i Press, 2009; P. Lejeune, Le Moi des demoiselles : enquête sur le journal de jeune fille, Edition du Seuil, 1993.

${ }^{49}$ N. Elias, An Essay on Time, in The Collected Works of Norbert Elias volume 9 S. Loyal and S. Mennell eds. University College Dublin Press, 1992.

${ }^{50}$ See for example B. Didier, "Pour une sociologie du journal intime," in Le journal intime et ses formes littéraires: Actes du Colloque de septembre 1975, comp. V. Del Litto (Geneva, 1978), 24548; A. Corbin, "Backstage," in A History of Private Life, vol. 4 From the Fires of Revolution to the Great War, M. Perrot ed. Cambridge, MA, 1990, p. 499.

51 The significance of publishers producing printed diaries as evidence of journal writing as an important cultural practice of the middle classes has been explored in the British context by S. Jung, 'The Illustrated Pocket Diary: Generic Continuity and Innovation, 1820-40,' Victorian Periodicals Review, Volume 45, Number 1, Spring 2012, pp. 23-48.

52 See Lefebvre, Rhythmanalysis, p. 15. for Lefevre's theory of temporality as rhythmic. See Also B.G. Smith, Ladies of the Leisure Class, pp. 53-92.

${ }^{53}$ Each year the Bourgeoise Parisienne marked the date of her mother's death. See entry for August 2, 1870, MS 31; entry for August 2, 1871, MS 32.

${ }^{54}$ Corbin, pp. 10-11.

55 On the idea of the nineteenth-century housewife as business manager see R. Wensley, "Isabella Beeton: Management Lessons from the Kitchen," Business Strategy Review 2004; 15(3): 66-72.

${ }^{56}$ La Salle à Manger, May, 1898, p. 2.

${ }^{57}$ Bourgeoise Parisienne, MS 31, entry for June 3, 1870.

58 Bourgeoise Parisienne, MS 31.

${ }^{59}$ Bourgeoise Parisienne, MS 31.

${ }^{60}$ Le Verrier, p. 71.

${ }^{61} \mathrm{Pau}$, Le Journal de Marie-Edmée, p. 1.

62 Pau, Le Journal de Marie-Edmée, p. 6.

${ }^{63}$ K. Lysack, 'The Productions of Time: Keble, Rossetti, and Victorian Devotional Reading,'

Victorian Studies, Volume 55, No. 3 (Spring 2013), 451-470. On Charles Sainte Foi and his publications see L. Veuillot, Notice sur Charles Sainte-Foi, sa vie et ses écrits, Impr. de L. Guérin (Bar-le-Duc), 1861, p. 13.

64 Pau, Le Journal de Marie-Edmée, p. 18 November 22, 1860.

65 Pau, Le Journal de Marie-Edmée, 14 August, 1860, p. 9.

${ }^{66} \mathrm{Pau}$, Le Journal de Marie-Edmée, p. 61, May, 1861.

${ }^{67} \mathrm{Pau}$, Le Journal de Marie-Edmée, p. 19.

68 Weiler, Journal d'une jeune fille mal dans son siècle, p. 64 Dec 5, 1841.

${ }^{69}$ For a reflection on the ways in which young women's diaries reveal the subjugation of their time to men's timetables, see J. W. Scott, "New Documents on the Lives of French Women: The Journal of Caroline B., 1864-1868.” Signs, vol. 12, no. 3, 1987, pp. 568-572.

70 le Verrier, Journal d'une jeune fille Second Empire, p. 24, Jan 1867.

${ }^{71}$ le Verrier, Journal d'une jeune fille Second Empire, p. 33, 28 Feb 1867.

72 Norbert Elias wrote about the importance of timekeeping in socialization of children. See $A n$ Essay on Time, Oxford: Blackwells, 1992.

73 Berthault, Journal.

${ }^{74}$ Berthault, Journal, p. 14.

75 Berthault, Journal, pp. 14-16.

76 Bourgeoise parisienne, Saturday 14 January 1871. The importance of letters in women's family relationships is eloquently explored in Susan Foley (2015) "Becoming a Woman: Self-Fashioning and Emotion in a Nineteenth-Century Family Correspondence", Women's History Review, 24:2, 215-233.

77 Laporte, "'Ne m'appelez donc jamais femme auteur"

78 Papiers George Sand, 1852. BNF NAF 24813.

${ }^{79}$ Sand, BNF NAF 24813.

${ }^{80}$ Sand, BNF NAF 248139 January, 1861.

81 Sand, BNF NAF 2481310 February, 1861

82 Sand, BNF NAF 2481311 February, 1861.

${ }^{83}$ H. Lefebvre, Rhythmanalysis: Space, Time and Everyday Life, S. Elden and G. Moore trans., London: Continuum, 2004. 
${ }^{84}$ For a lengthier discussion on prescriptive sources for social history see R. Rich, "'If you desire to avoid life, avoid unpunctual people": Women, Timetabling and Domestic Advice, 1850-1910,' Cultural and Social History, 12: 1, p. 97.

85 'Le Courrier de Paris' L'Illustration, 10 March, 1860, carried a feature on onion soup as a fashionable alternative to meat-based broths during Lent, which was typical of the intermingling of linear and cyclical time in cookery writing.

${ }^{86}$ Pot-au-Feu, 1, April, 1892, p. 10.

${ }^{87}$ Brévaire du gastronome, p. 72.

${ }^{88}$ Bréviaire du gastronome, pp. 69-75.

${ }^{89}$ Bréviaire du gastronome, pp. 91-2.

${ }_{90}$ Manuel des bons maîtres, pp. 8-9.

${ }^{91}$ Manuel des bons maîtres, p. 9 .

${ }^{92}$ Manuel des bons maîtres, p. 9.

${ }_{93}$ Manuel des bons maitres, p. 24.

${ }_{94}^{94}$ Manuel des bons maîtres, p. 26.

${ }_{95}$ Manuel des bons maîtres, p. 26. See also A Corbin, Time, Desire on the great diversity of mealtimes in nineteenth-century France, pp. 1-2.

${ }^{96}$ Manuel des bons maîtres, pp. 30-1.

${ }_{97}$ Un ancien Cordon Bleu, Nouveau Manuel de la Cuisinière Bourgeoise et Economique, Paris: Bernardin-Bechet, n.d. [c. 1850], pp. 6-8.

98 Corbin, p. 8.

${ }^{99}$ Corbin, p. 8.

100 Un ancien Cordon Bleu, p. 5.

${ }^{101}$ Un ancien Cordon Bleu, pp. 300-3.

${ }_{102}$ Caroline Lieffers argues that in the nineteenth-century cookery writers took an increasingly scientific approach to their subject, and advances in cookery came to be conflated with the progress of civilization. 'Science of Cookery in Nineteenth-Century Britain,' p. 951.

${ }^{103}$ S. Pennell 'Professional Cooking, Kitchens, and Service Work: Accomplished Cookery' in B. Kumin ed., A Cultural History of Food in the Early Modern Age, Bloomsbury, 2016, p 114. 104 Maitte et Terrier, p. 6.

105 A. T. Raimbault, Le Parfait Cuisinier ou le bréviaire des gourmands, Paris: Haut Coeur et Gayet, 1822, p. 16.

106 Raimbault, p. 42

${ }^{107}$ Raimbault, pp 50-1.

108 D. L. [Lerignet?], La Cuisine Elémentaire et Economique, Propre à toutes les conditions et tous les pays, $2^{\text {nd }}$ ed. Paris: Levacher, An XIII-1805, p. 39.

${ }^{109}$ Borel, Nouveau Dictionnaire de Cuisine, D'Office et de Pâtisserie, Paris: Chez Coubert Aine, 1826, p. 646 .

${ }^{110}$ Ancien Cordon Bleu, p. 107.

${ }^{111}$ Anon, Traité sur la Bonne Cuisine Bourgeoise in Manuel des Bons Maîtres et des bonnes servantes, p. 156.

112 Dubois, La cuisine de tous les pays, p. 145

113 Dubois, Ibid. p. 147. 